\title{
A STUDY OF THE CONSERVATION SIGNIFICANCE OF PIRZADA MANSION, LAHORE, PAKISTAN
}

\author{
A. M. Malik* \\ M. Rashid** \\ S. S. Haider*** \\ A. Jalil****
}

\begin{abstract}
Built heritage is not merely about living quarters, but it also reflects the living standards, cultural norms and values of any society. The old built heritage gives references to the past, the way people used to live and their living arrangements. This is done by understanding the spatial layouts of that particular built heritage. This research aims to focus on documenting a historic building from the colonial period located in the walled city of Lahore, to highlight the need and significance of conservation of these historical buildings that are neglected and under threat. The method of research adopted for this paper was to document this building via an ethnographic analysis using photographic surveys, questionaires, interviews from government authorities (Walled City of Lahore Authority) and local residents, and several site visits for detailed documentation. This paper aims to identify the aesthetics and structural threats and other aspects of the Pirzada Mansion, which is a splendid example of the British colonial period and is located in Walled City of Lahore.
\end{abstract}

Keywords: Pirzada Mansion, Walled City, Deterioration, Damage, Conservation, Lahore.

\section{INTRODUCTION}

Lahore is a multi ethnic city filled with diverse architecture belonging to different areas. It is the capital of the province of Punjab, the most fertile area of Pakistan and the chief producer of agricultural products for the country. The earliest credible records of the city date its establishment to around
1050 , which shows that its existence was due to its placement along the major trade route through Central Asia and the Indian subcontinent. The city was regularly marred by invasion, pillage, and destruction (due to its lack of geographical defenses and general over exposure) until 1525, when it was sacked and then settled by the Mughal emperor Babur. Sixty years later it became the capital of the Mughal Empire under Akbar, and in 1605 the Fort and city walls were expanded to the present day dimensions. From the mid-18th century until British colonial times, there was a fairly lawless period in which most of the Mughal Palaces (havelis) were destroyed, marking a decrease in social norms and association with the built environment, that has continued unabattingly till today. Much of the walled fortification of the city was destroyed following the British annexation of the region in 1849, as both a defensive measure to allow the colonists to better control the city and because of a commercial objective in order to resale the bricks for new projects (PEPAC, 1993). In 1864 many sections of the wall had been rebuilt. Major physical contributions of the British to the old city consisted of piped water and well system, established right outside the former walls. The building of the railroad and a station well outside the old city, set the stage for later expansion. A new wave of destruction washed over the city in 1947, following the partition of British colonial India into the Hindu majority nations of India and the Islamic Republic of Pakistan. The resulting intercommunal strife destroyed wide areas of the urban fabric, some of which was repaired by the 1952 Punjab Development of Damaged Areas Act. Many of the arriving Muslim families from India moved into the emigrating Hindu residences,

\footnotetext{
* A. M. Malik, Assistant Professor, School of Architecture and Planning, University of Management of Technology, Lahore, Pakistan. Email correspondance: ayesha.malik@umt.edu.pk

** M. Rashid, Assistant Professor, School of Architecture and Planning, University of Management of Technology, Lahore, Pakistan. Email correspondance: meoona.rashid@umt.edu.pk

*** S. S. Haider, Assistant Professor, School of Architecture and Planning, University of Management of Technology, Lahore, Pakistan. Email correspondance: sajjad.haider@umt.edu.pk

**** A. Jalil, Assistant Professor, School of Architecture and Planning, University of Management of Technology, Lahore, Pakistan. Email correspondance: adnan.jalil@umt.edu.pk
} 
although the low land values of the old city established the concentration of lower income groups in the city center, with wealthier families residing outside the fortification wall. In the 1950's an organization called the Lahore Improvement Trust attempted to initate a plan for commercial development in the old city, but these efforts were largely without effect. Between the early 1970s and ' 80 s, $29 \%$ of the old city population moved out. The Walled City of Lahore is the product of the cultural influences of atleast three major empires in the subcontinent of India: the Mughal Empire, the British colonial presence, and the modern nation-state of Pakistan. As a result of its position along a major trade route, it has also been influenced by many other, less dominant cultures, such as Afghanistan and China. Unlike Peshawar, which has lost much of its larger scaled architectural past, and Islamabad, which can only boast modern monumental architecture of some merit, Lahore contains some of the best expmples of all the empires which have touched it, as well as smaller scale vernacular architecture.

\section{SELECTION OF THE PIRZADA MANSION}

The Walled City of Lahore is enriched with a multidiversified timeline from Mughal to Sikh great British architecture. History has left buildings from all the eras (both original and transitions of the either two eras) (Table 1, Figures 1 and 2). A lot of work has been done in order to preserve these historic legacies yet a few are still untouched and are under severe threat. There are many glorious buildings from the Sikh colonial period that show splendid architectural elements of the two periods, out of which the Pirzada Mansion is selected for this study, based on its architectural and regional milieu. This building has private ownership and there are no such national policies that apply on it.

\section{LOCATION}

Pirzada Mansion is an old Haveli located on Fort Road, in close proximity to the Lahore Fort, Badshahi Mosque and the Walled City. The area of the haveli is 3880 sq.ft. It was constructed in the colonial period and is called "Pirzada Mansion", also known as Peerzada House.

Table-1: Famous Sikh Colonial Havelis in Walled City During Sikh and British Eras.

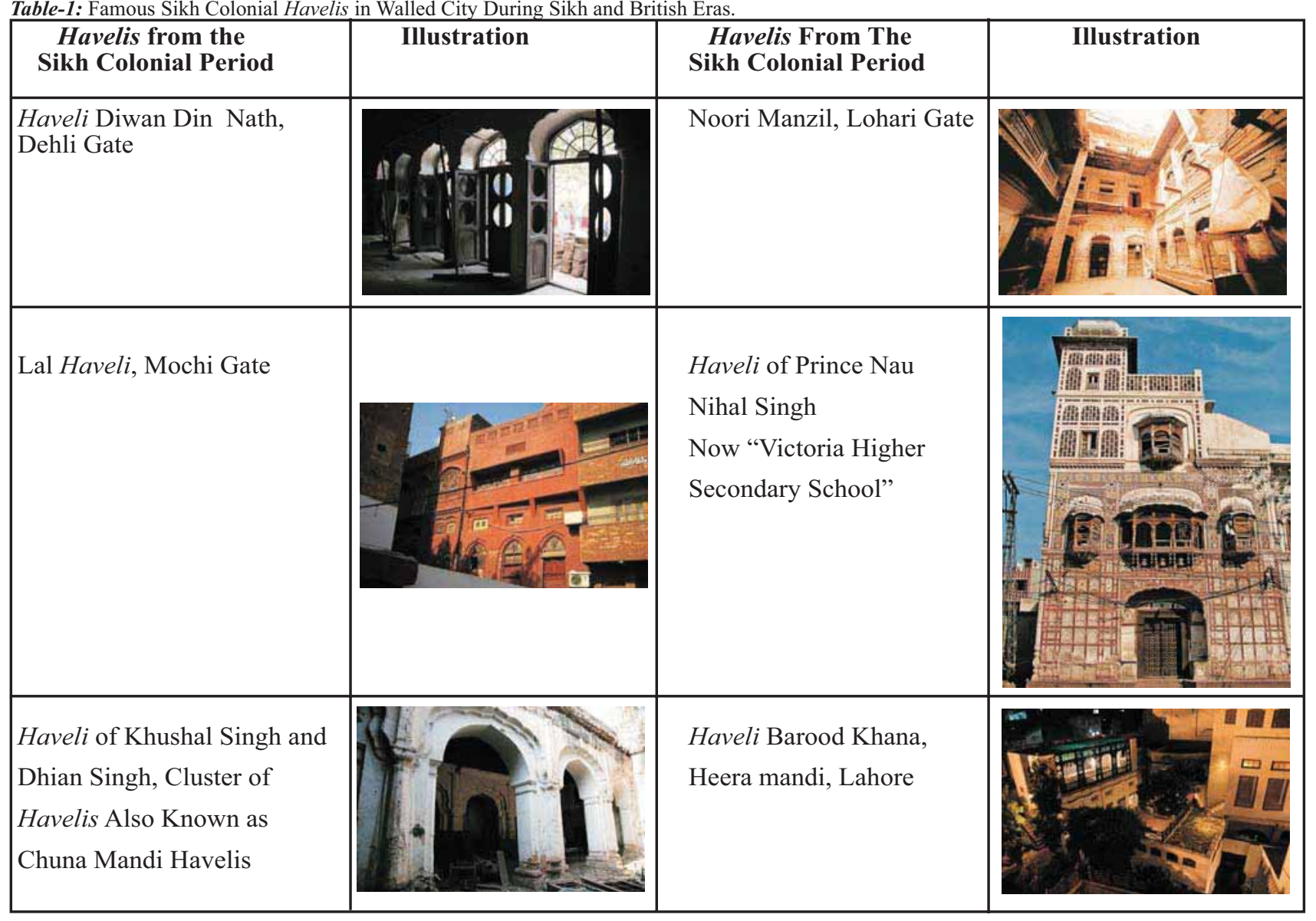




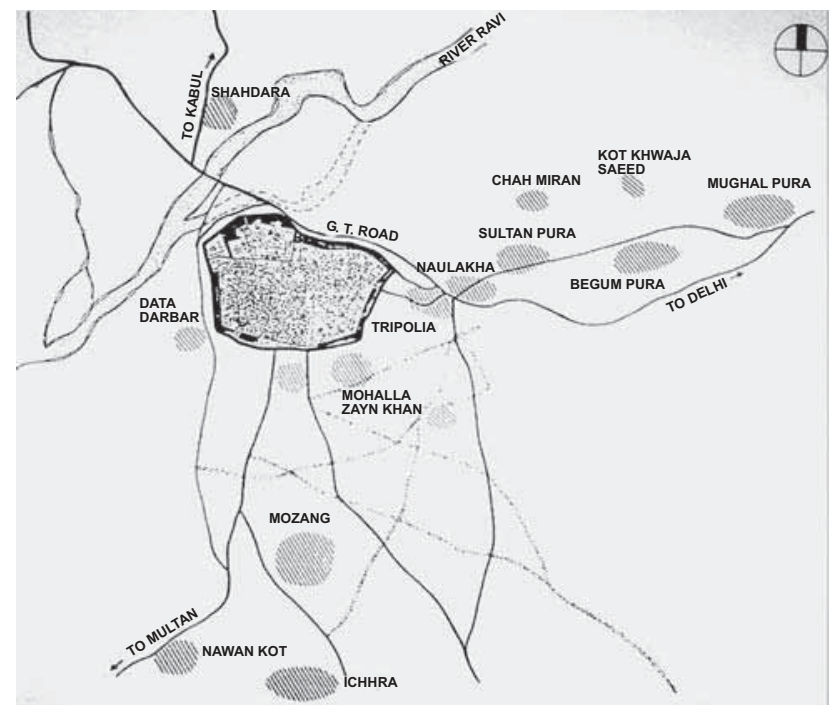

Figure-1: Location of havelis outside Walled City of Lahore.

The site of Pirzada Mansion is located in the oldest part of Lahore, approximately three hundred meters from the 'Roshnai' Gate of the 'Walled City', connecting to the Fort

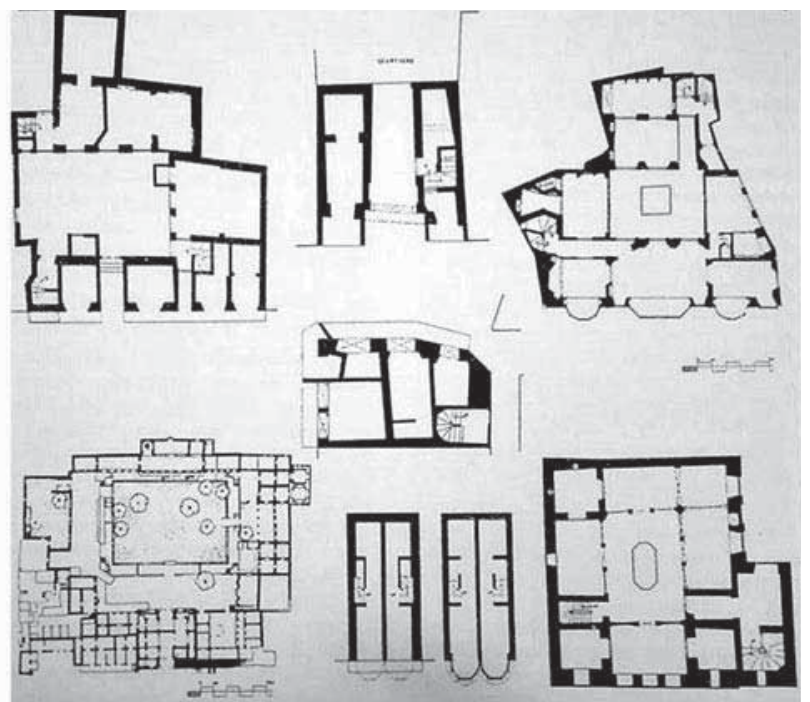

Figure-2: Examples of plans of havelis in Lahore.

and Grand Mosque complex (Figure 3). During the British rule the wall of the city was demolished and the esplanade of the Fort complex, where the site is located, was inhabited.

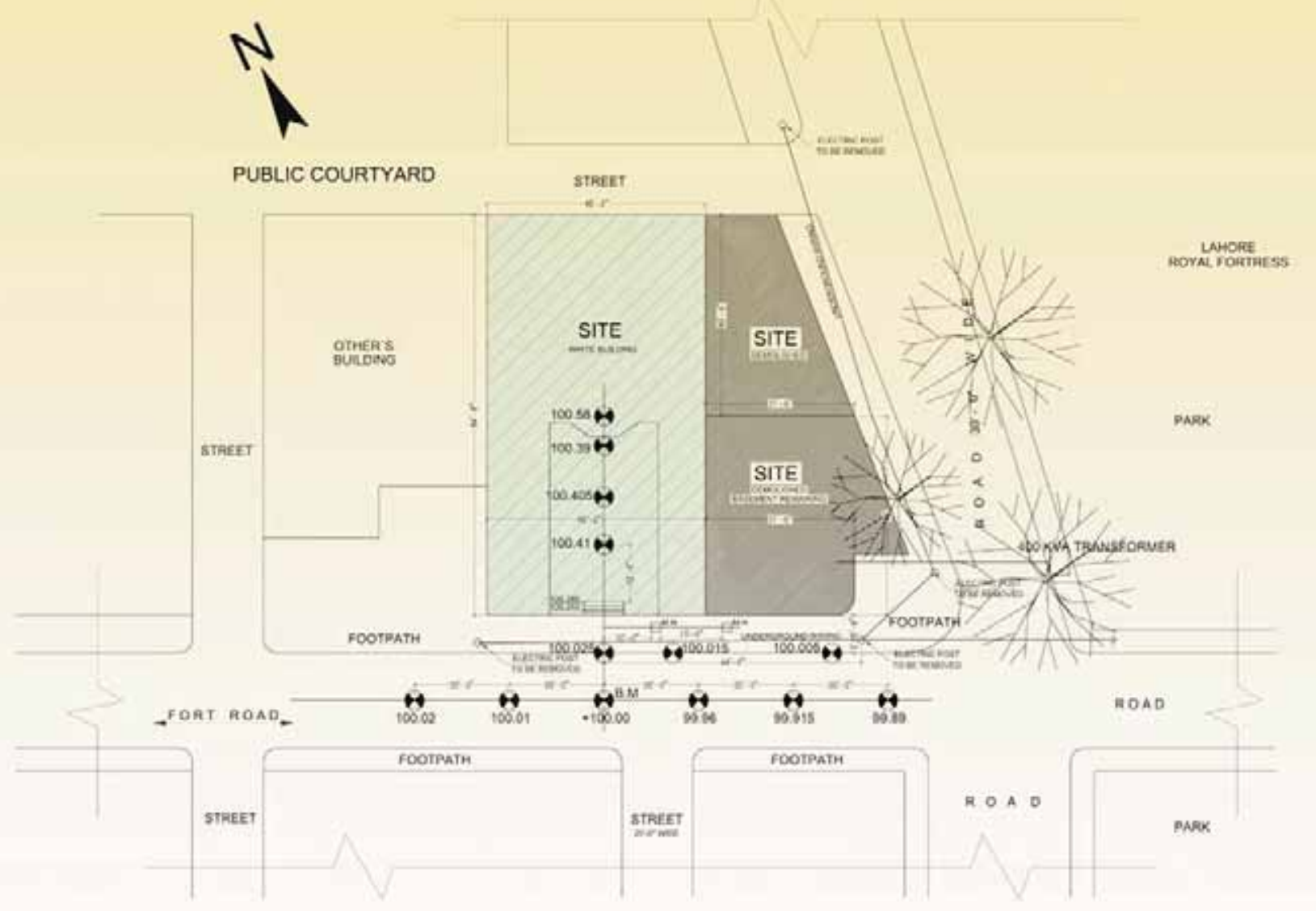

Figure-3: Pirzada Mansion's (Haveli) location plan. 
The Fort Road, along the southern façade and main entrance of the haveli, has since then become one of the main vehicular routes into the 'Walled City'. The northern (rear) gate of the haveli opens into a courtyard across which lies the famous 'Cuckoo's Café'(Figure 4). The eastern wall faces the outer fortifications of the Lahore Fort. To the west of the consolidated property, a $9 \mathrm{ft}$ wide lane connects the Fort Road to the rear courtyard space.

The main building, as suggested by a plaque on its north entrance, dates to 1930 and was built in the name of Lala Sita Ram Mehra, the Municipal Commissioner, and son of late Gobind Ram Sahib, a lawyer in High Court Punjab. The construction of the mansion is a fine example of local traditional and decorative techniques. The roof top vista provides a commanding view of the Badshahi Mosque, the Lahore Fort and Gardens. The name 'Pirzada Mansion is inscribed above the southern entrance door, suggesting a change of ownership after the partition of the Sub Continent. It is a five story plus one (mumty floor plan) structure, of approximately $57 \mathrm{ft}$ height. The construction of the haveli comprises of traditional brick and kankar lime.

\section{RESEARCH METHODOLOGY}

The research was based on ethnographic analysis of the area and the building occupancy, thus the data for this study was collected from various sources of historic literature, architectural offices (project based research), books, research papers, newspaper clippings, interviews (local authorities), questionnaires (from occupants of the area). The data was further verified by the examination of the building. Frequent visits of the site were also done to enhance the documentation. The collected data was then analyzed with reference to the urban configuration of horizontal and vertical arrangements of the structure, its present condition and the need for conservation.

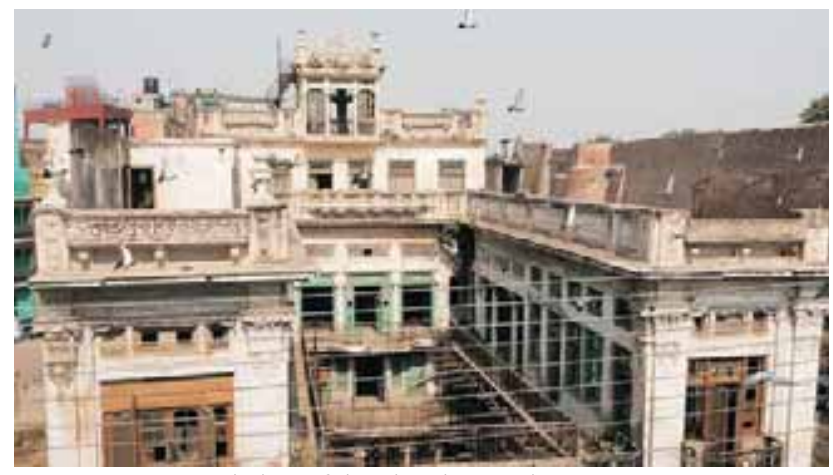

Figure-5: External view of the Pirzada Mansion.

\section{RESULTS AND DISCUSSION}

After a detailed study of the Pirzada Mansion many historical and cultural evidences were revealed, that indicated its architectural significance (Figures 5 and 6). Pirzada Mansion is one gem among all the colonial era buildings found here. It seems to be inspired in style and design by buildings conspicuously popular among the Sikhs, primarily the

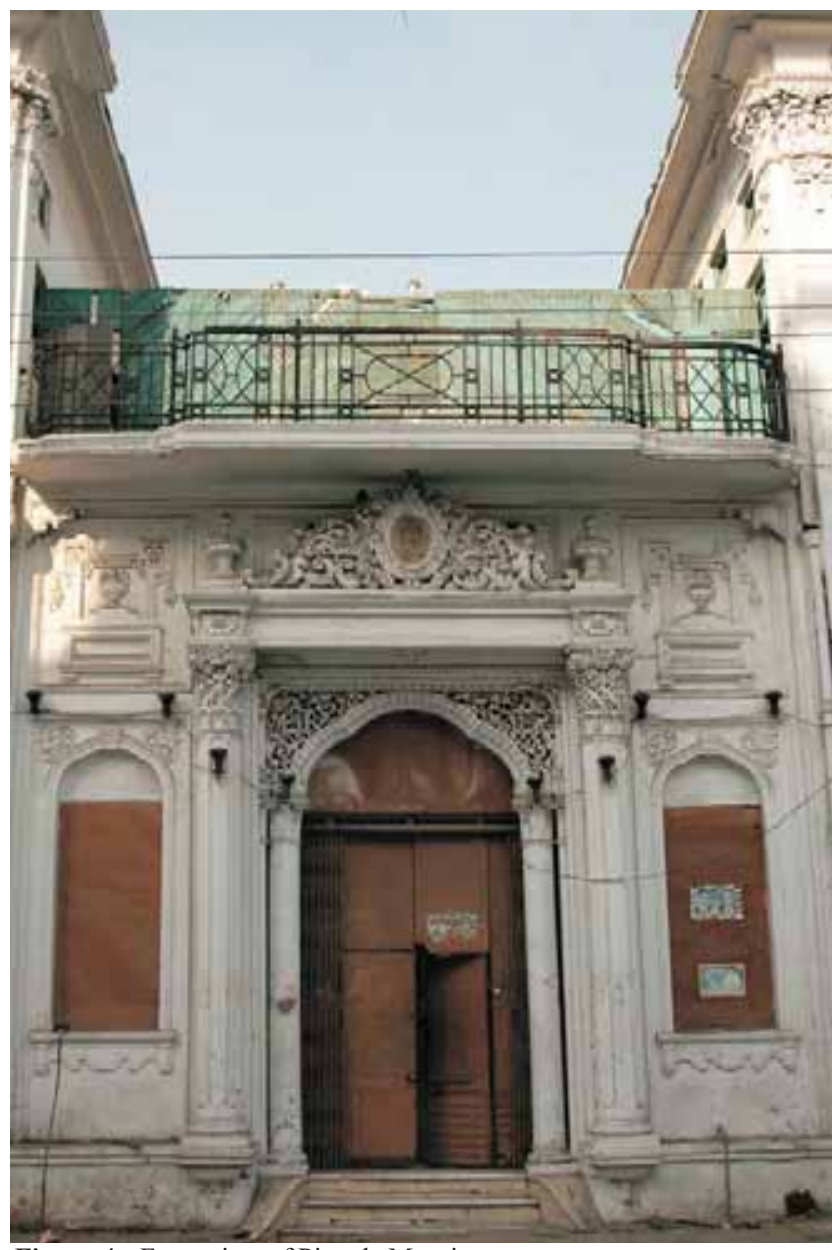

Figure-4: Front view of Pirzada Mansion.

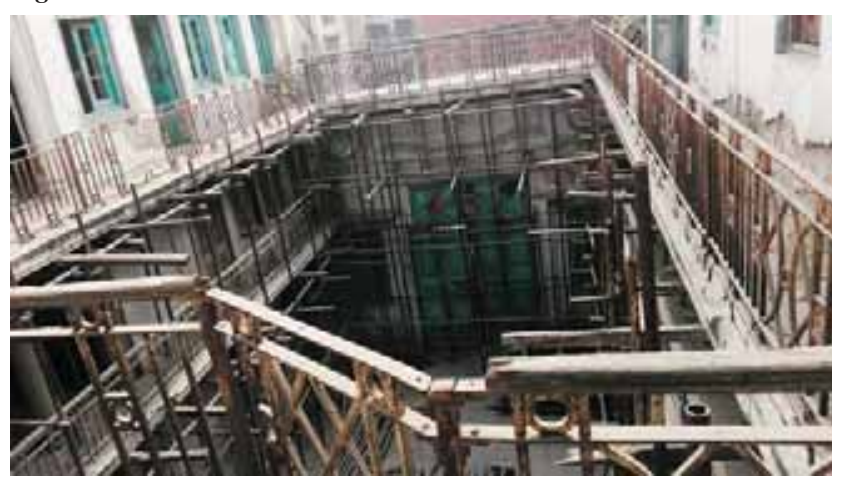

Figure-6: Internal view of the Pirzada Mansion. 
religious monuments. Their secular edifices such as fortresses, palaces, samadhis (mausoleums built over places of cremation), havelis (fortified houses), bungas (residential cum educational houses) and educational institutions, are no different from the contemporary style which is generally a mixture of Mughal and Rajput Architecture, or as Percy (Browne, 1942) an art historian, has described, a late form of the Mughal style of architecture.

\section{Architectural Significance}

Prominent examples of this type of architecture are the Samadhi of Maharaja Ranjit Singh in Lahore and the Khalsa College in Amritsar. Whereas massive columns, portals, inner structures, bukharchas (three or four paneled projecting windows in a row) on penda or gharvahj (projecting base) in the shape of bisected open lotus, the chhatns (kiosks) on the parapet, all trace back their origin to Rajput Architecture. The dome, arches, minarets and underground cellars bear the stamp of Mughal style architecture (Figure 7). Religious buildings of the Sikhs, the gurdwaras, also display essentially eclectic nature of the architectural design, but they at the same time possess some special features, and present an identifiable picture of a style which can doubtlessly be called Sikh architecture.

One of the major distinctive features of Sikh shrines seems to be the presence of pillars and pilasters. The shafts are mostly plain, without any carving, except the vertical lines of accession. The capitals consist of floral or foliage designs (Figure 8). Some of the noticeable architectural features found in these building are jharokas, carved wooden doors, raised platforms, massive columns, floral ornamentations, Rajput architecture arches, bas-reliefs of geometrical, floral and other designs, interior - stucco work, fresco paintings, column friezes based on vine, plant, flower, bird, animal motifs and windows with jaalis (Arshi, 1985). The Pirzada

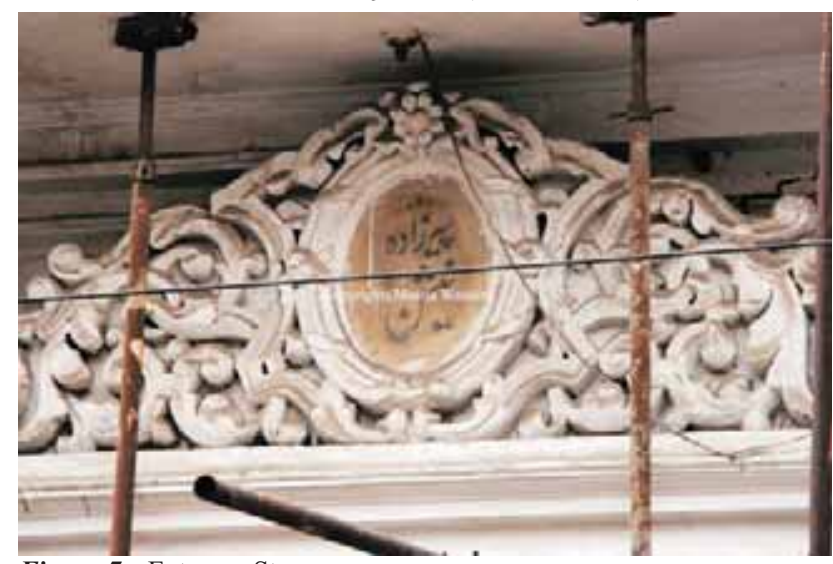

Figure-7: Entrance Stone. house has a basement, ground floor, first floor, mezzanine floor, second floor and top floor (mumty floor), with the centralized courtyard that is supported by columns, thick walls of 13 inches. The courtyard makes the building warmer in winters and cooler in summer, and protects the severe weather to enter the building. Some changes have been incorporated in the last 40 years in which rooms near the back entrance have been repaired the entrance of the basement has been closed for security issues, decorative columns have been replastered and the room on the front also has been replastered. Furthermore, the stair near the back entrance of the haveli has been altered.

The layout of the haveli is similar to the typical plans of havelis having a courtyard and a central space around which different rooms have been arranged (Figures 10-15).

The haveli was built in the traditional brick and kankar lime' construction. Repairs have been done in portland cement mortar. The columns are massive and reflect a design style beloging to that period and can be noticed in the elevation (Figure 16). The columns are based on vine, plant, flower, bird and animal motifs. (Figures 18-20). The main entrance to the haveli is decorated with floral designs.

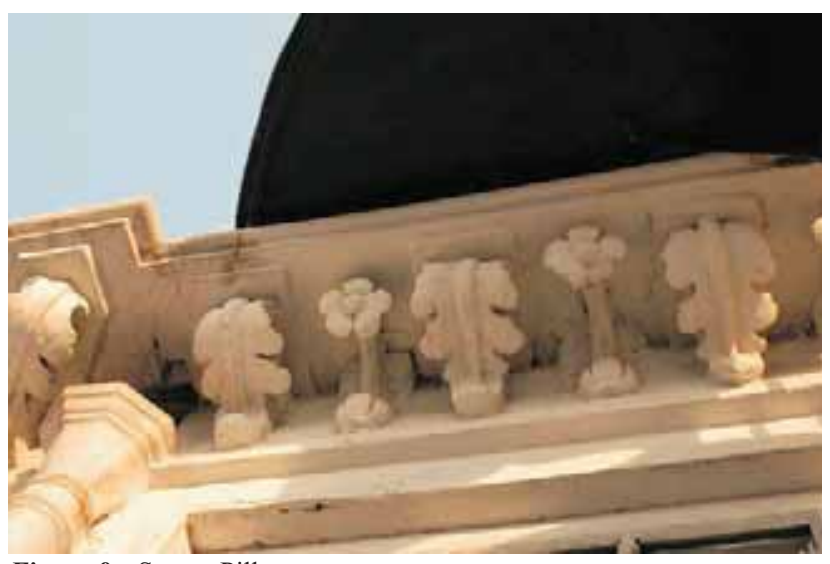

Figure-8: Stucco Pillar.

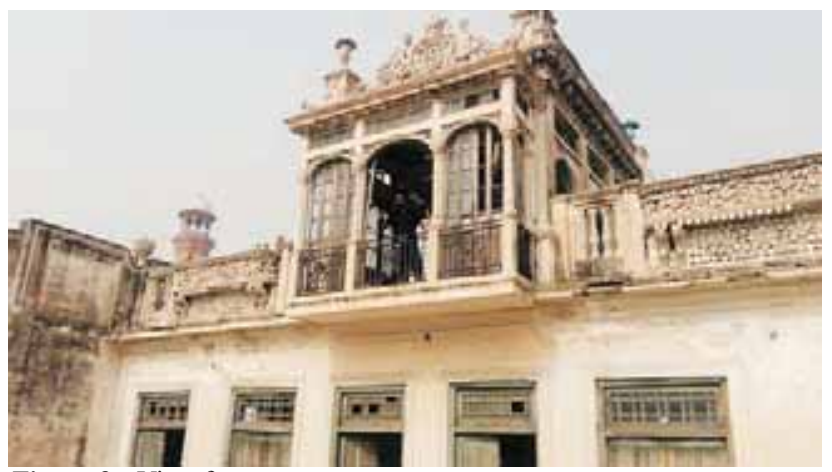

Figure-9: View from top. 


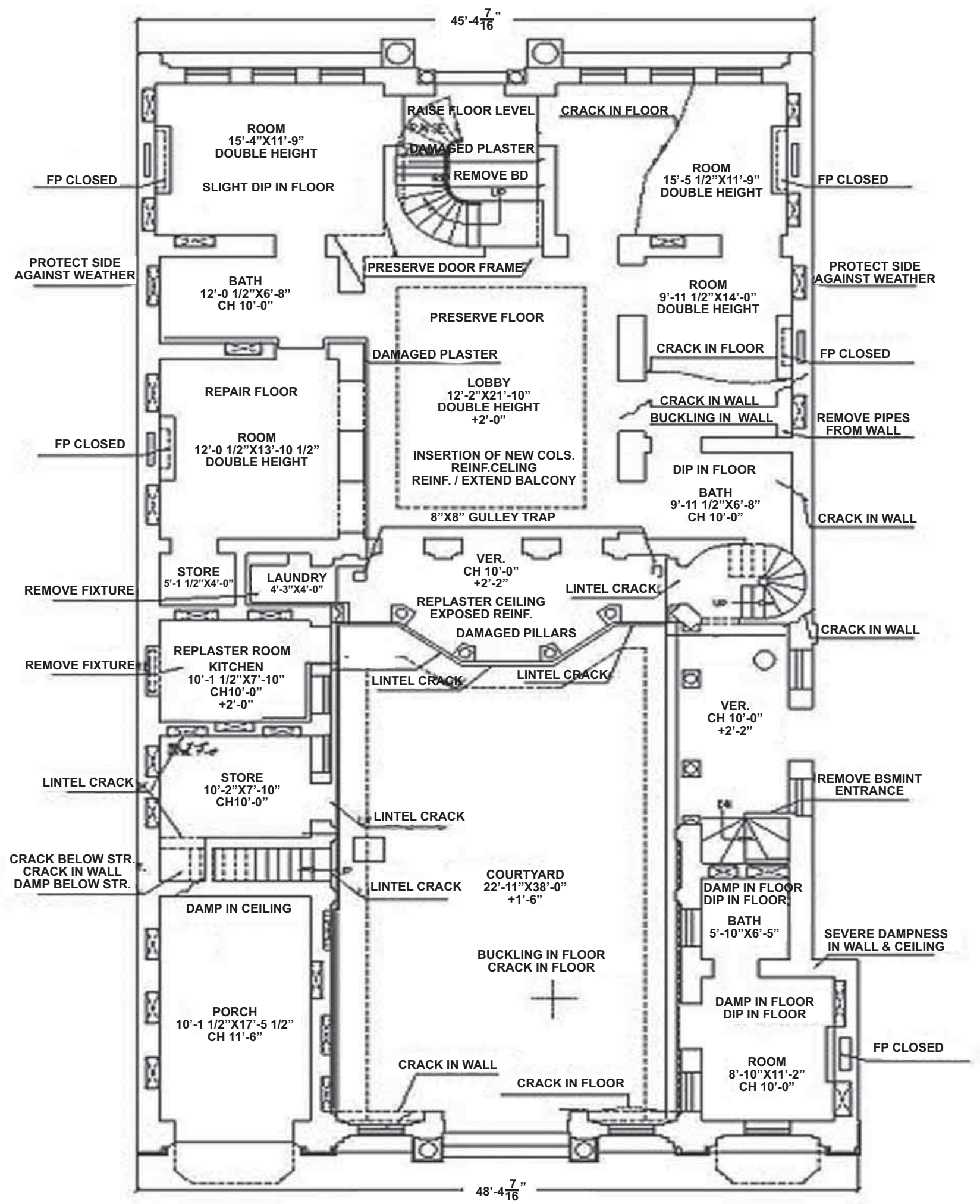

Figure-10: Ground floor plan. 


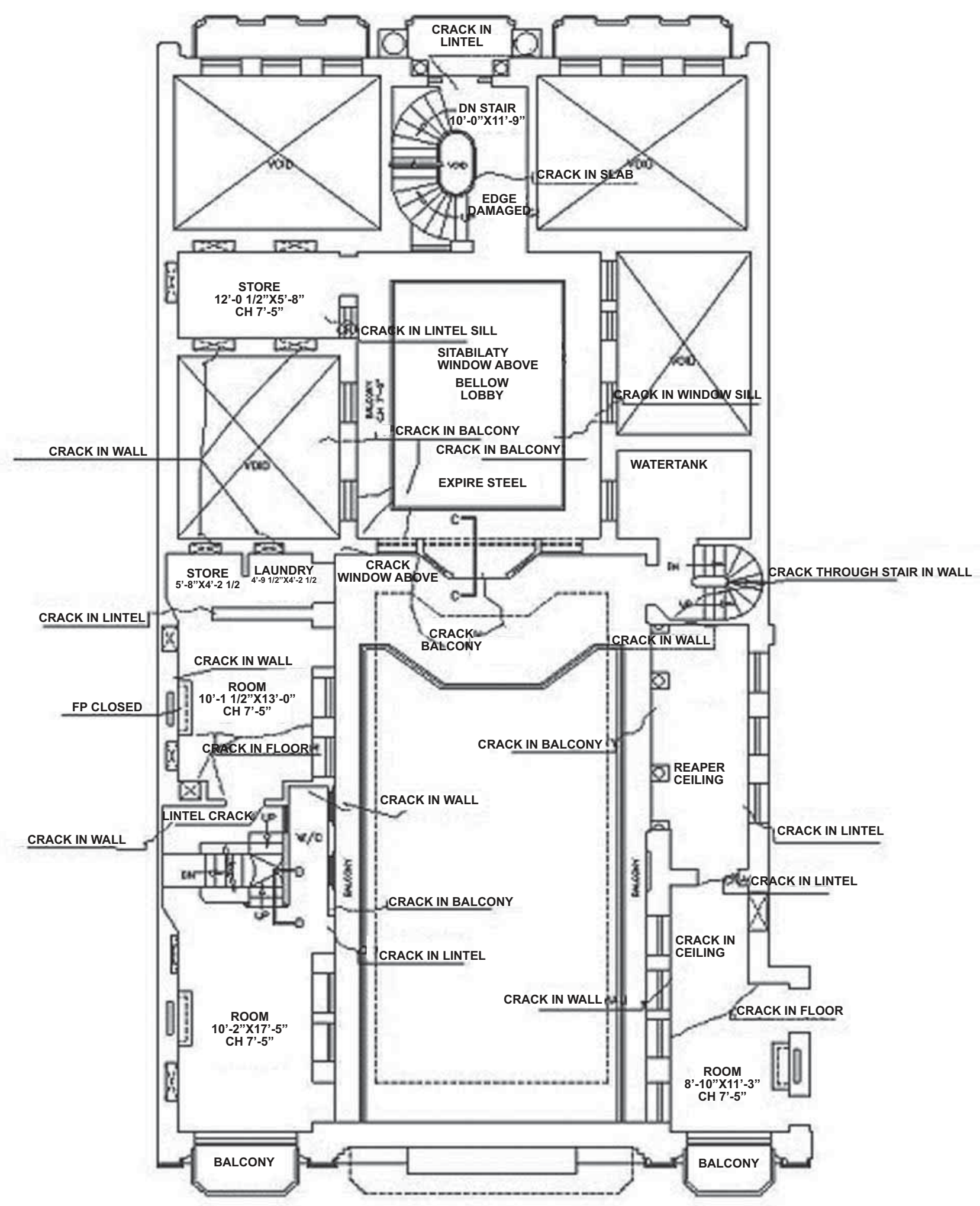

Figure-11: Mezzanine floor plan. 


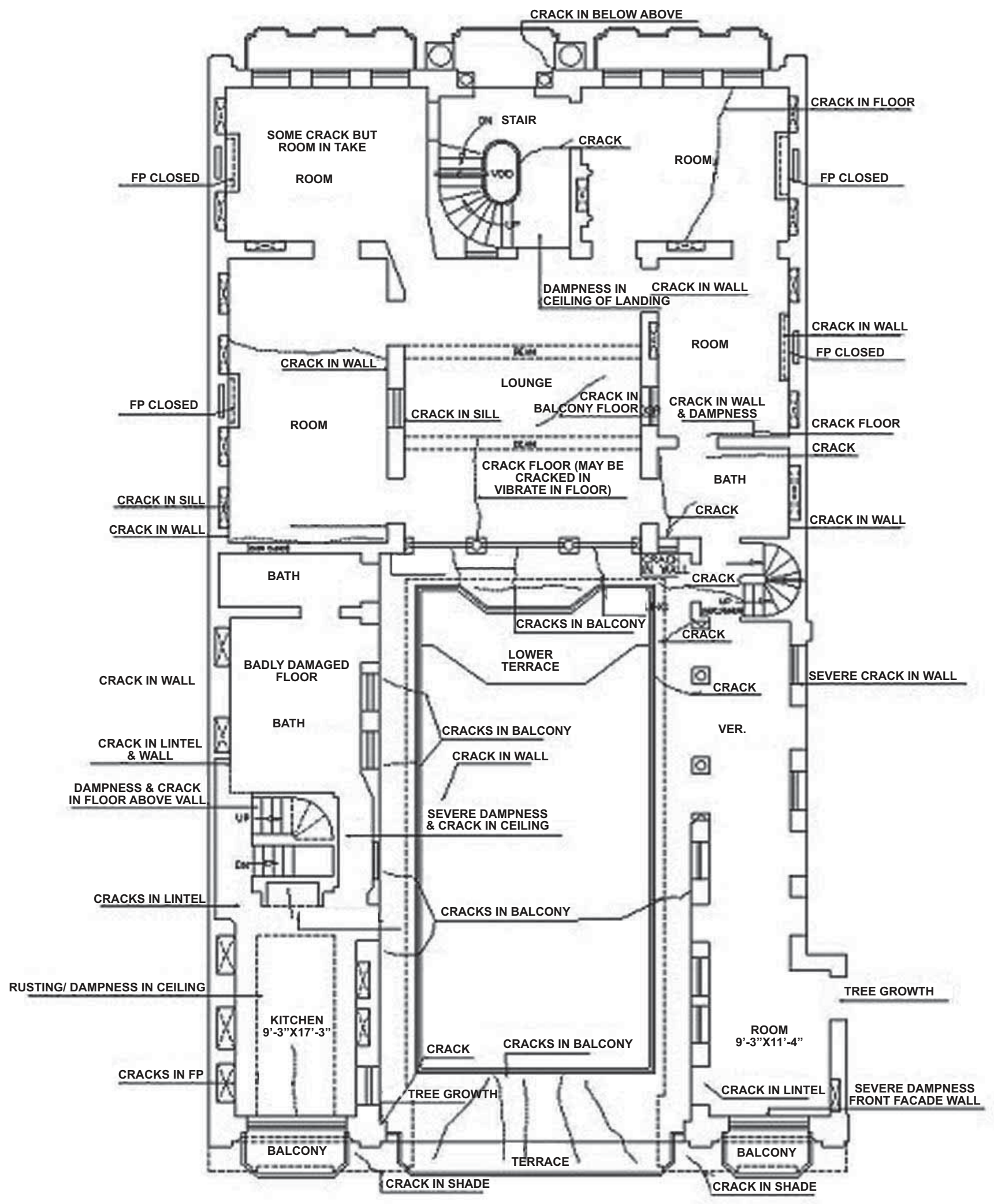

Figure-12: First floor plan. 


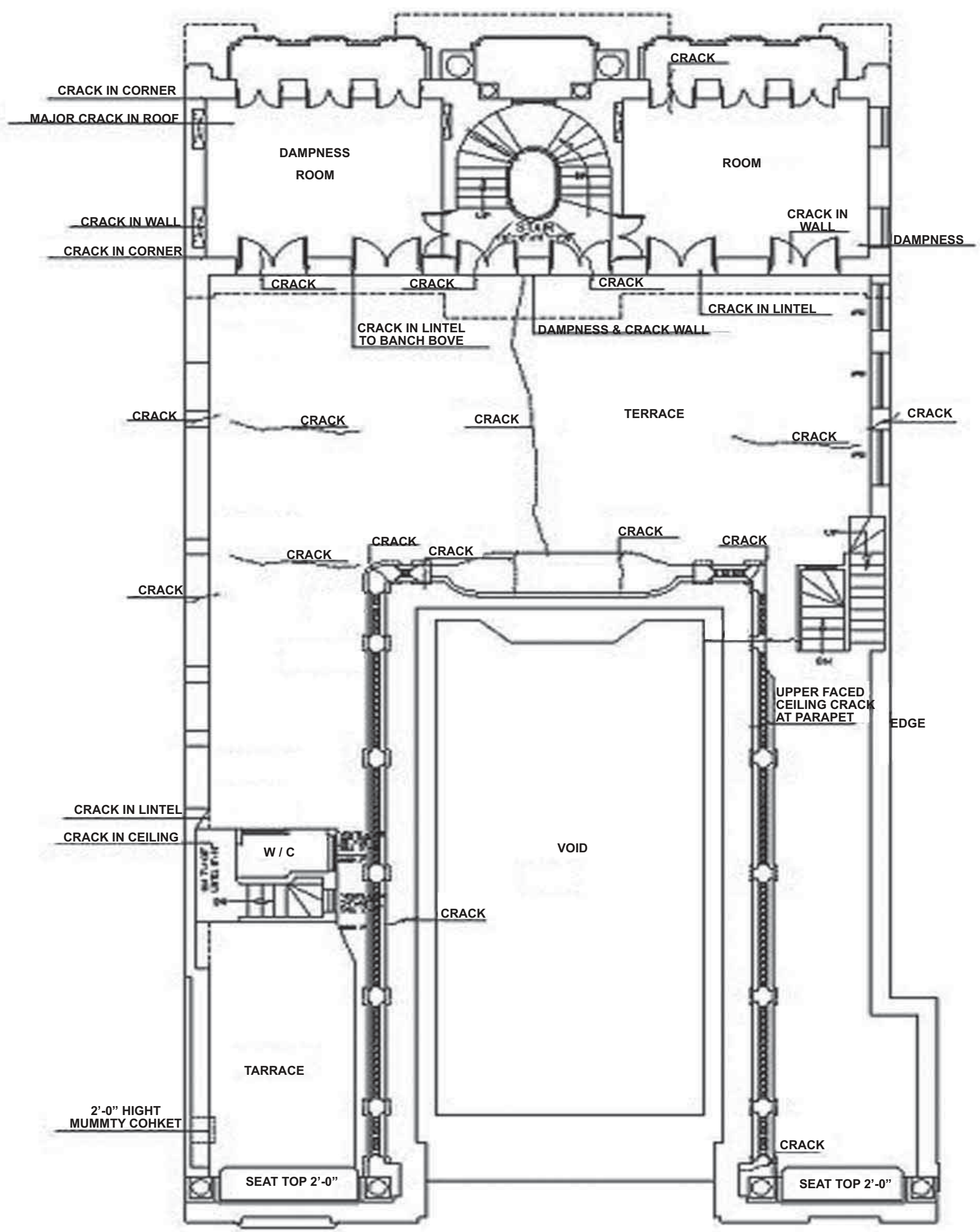

Figure-13: Second floor plan. 


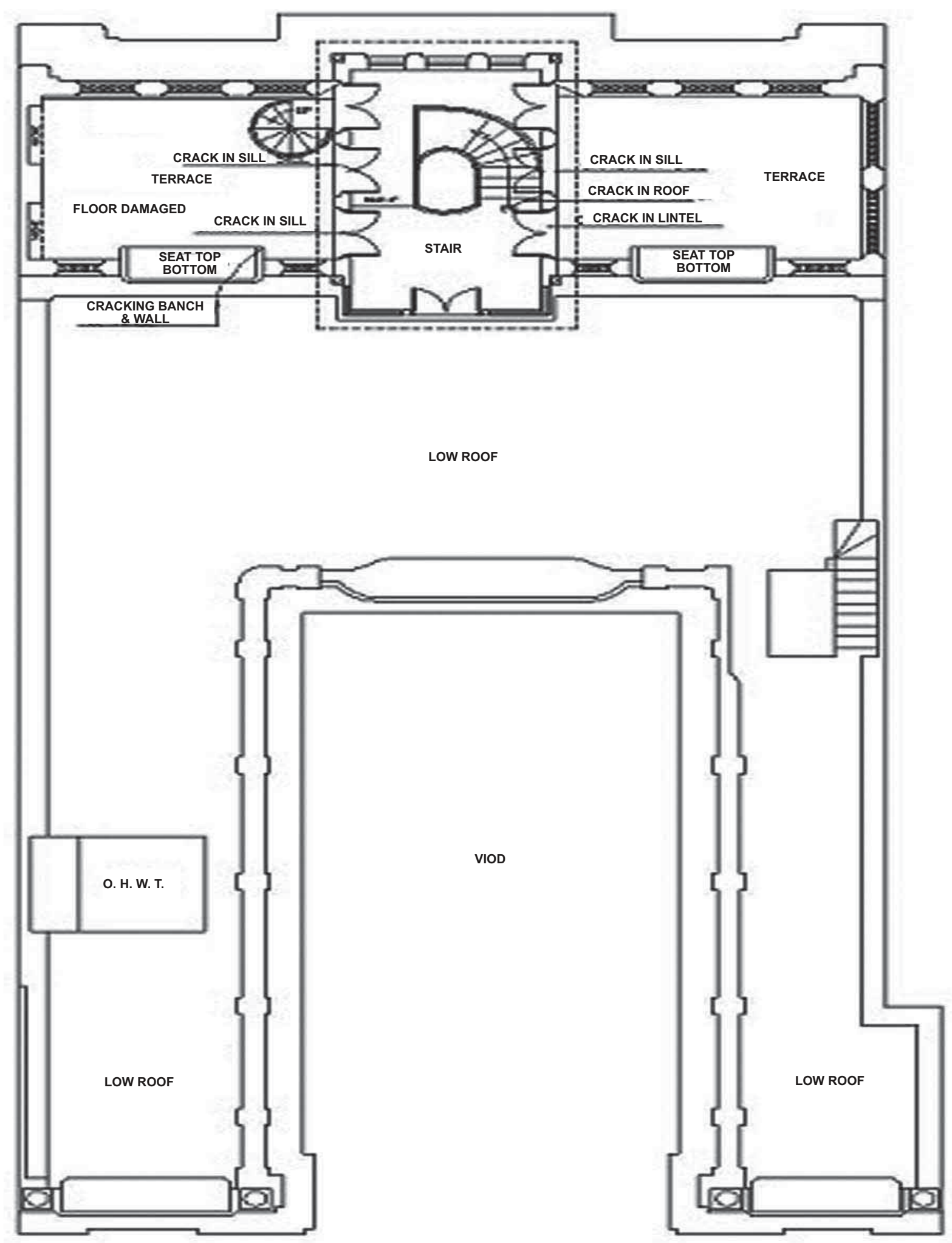

Figure-14: Mummty floor plan. 


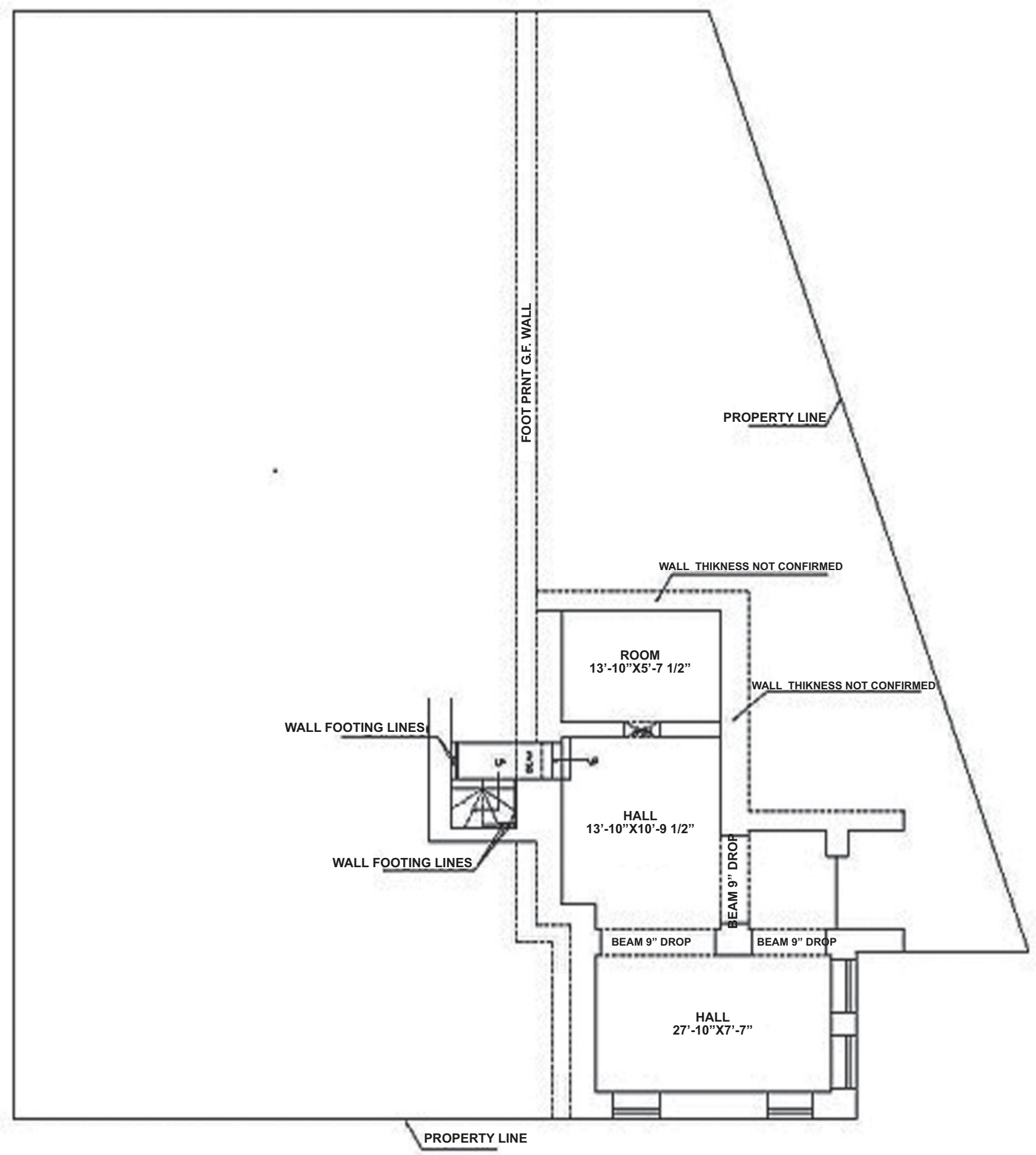

Figure-15: Basement plan. 


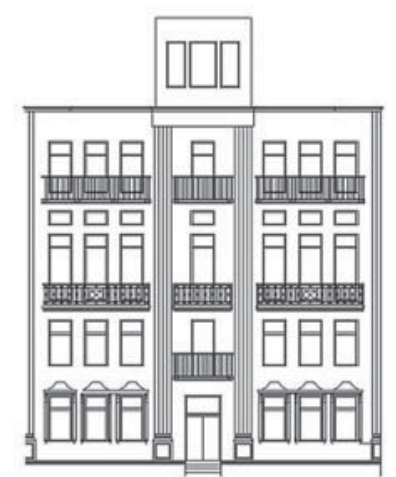

Figure-16: Front and side elevations.
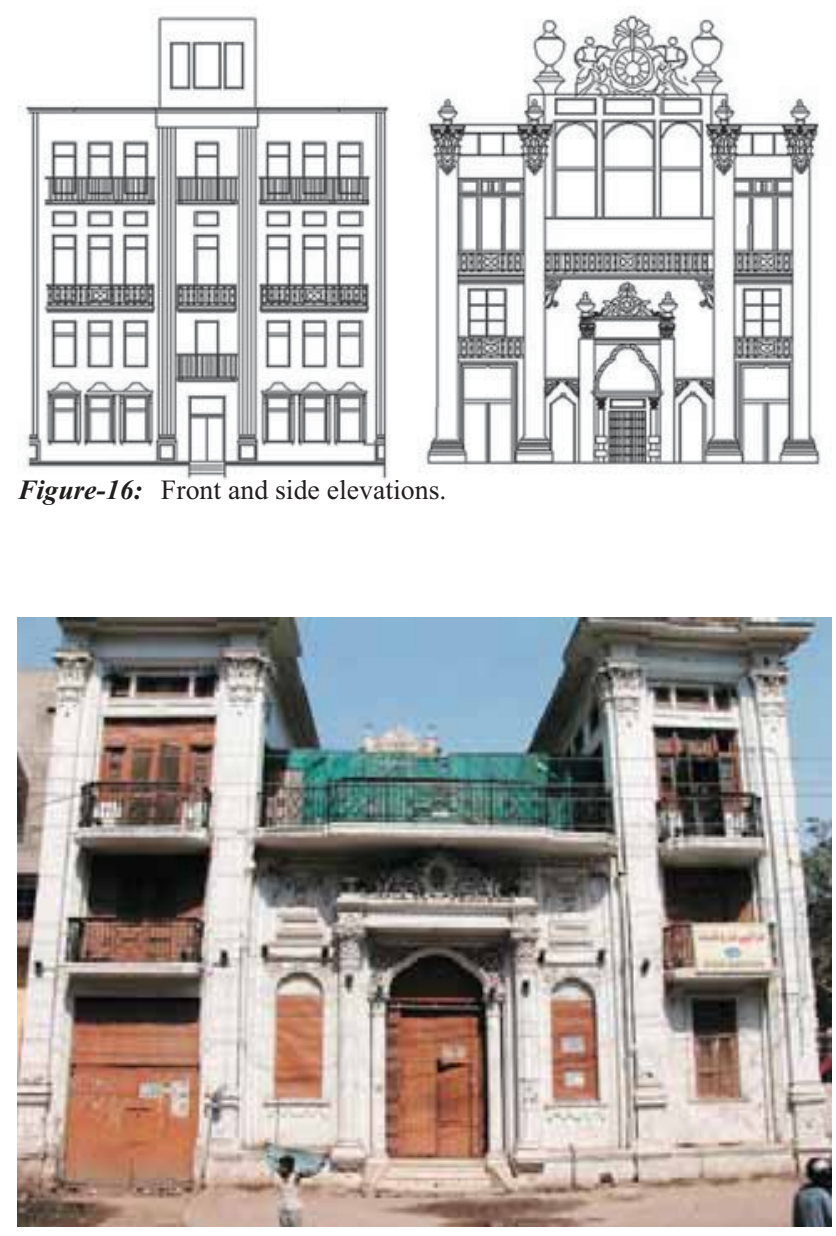

Figure-18: Front façade of the haveli.

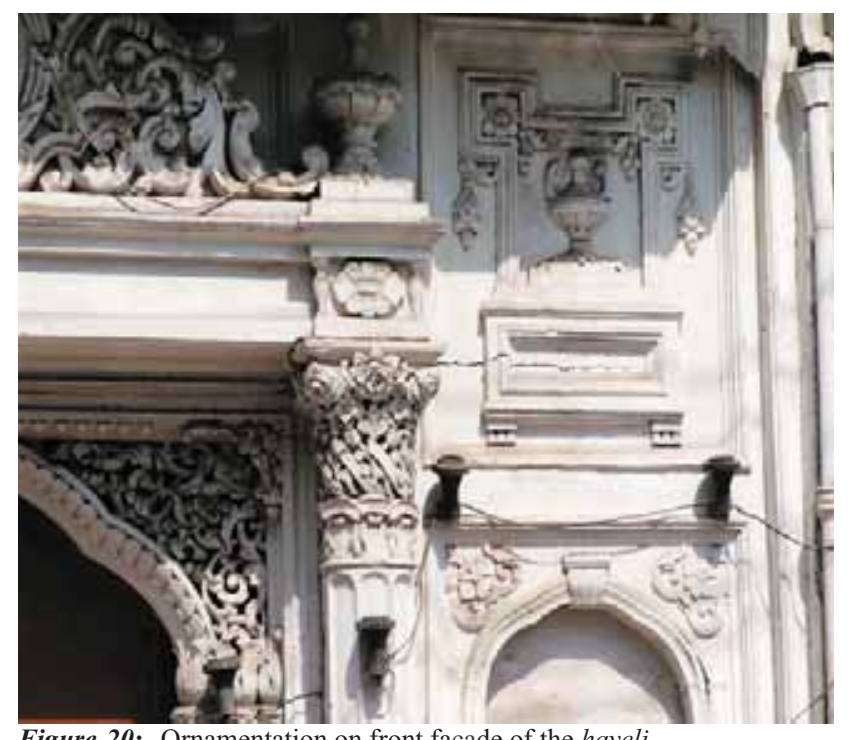

Figure-20: Ornamentation on front façade of the haveli.

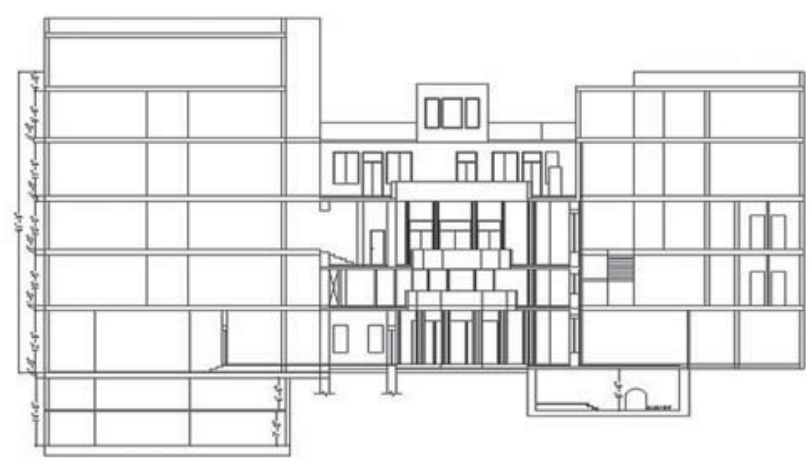

Figure-17: Section.

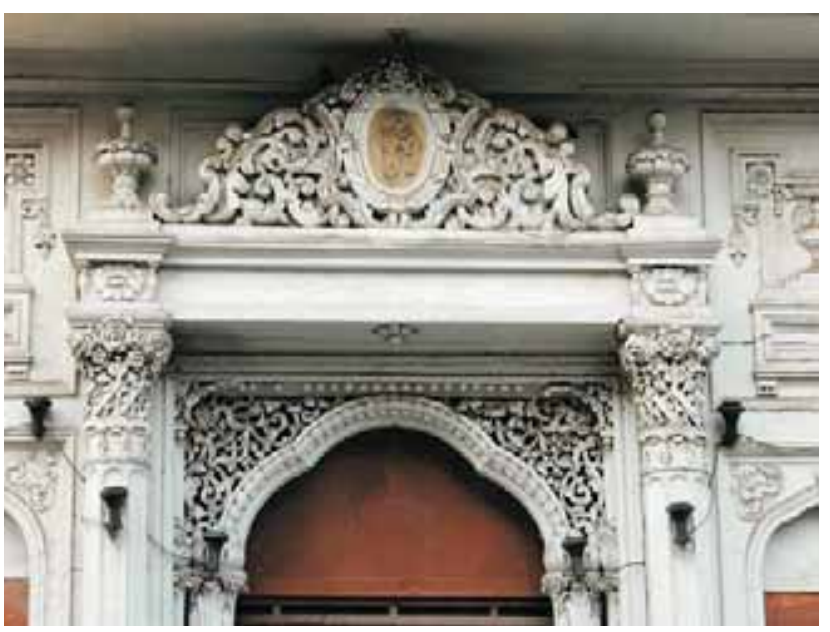

Figure-19: Architectural elements adorning the front façade.

In the interior, doors and windows are made of wood. They mostly have an arched profile (Figure 21). The number of windows and jharokas indicate the affluence of the owner. The havelis of the time were commonly known for the amount of wooden windows and carved doors (Fatima, 2013). The windows at the top have painted glass; they were used for generating patterns with the help of sunlight within the building. The arches were a common part of the buildings from that era, and were mostly taken from the Rajput architecture, hence the name Rajput arches (Figures 22- 23).

It is understandable from the plans that the mumty floor had terraces on both sides, with a staircase on the left one (Figures 24-25). The roof top vista provided a commanding view of the Grand Badshahi Mosque, the Fort and the Gardens. As the haveli is located in a sandwiched plot the front façade is most important from conservation point of view. The rear elevation is shown in Figure 26. 
The haveli is located on a street that is only $35 \mathrm{ft}$ wide. There are no compulsory open spaces left between buildings, and there were no bye-laws that were enforced at the time of the construction of the haveli. So the ventilation and air circulation is from the central courtyard of the haveli, that is around eighteen feet in width and thirty four feet in length, with the doors and windows opening into it (Figure 27). The perepheral walls, including the mezzanine floor are

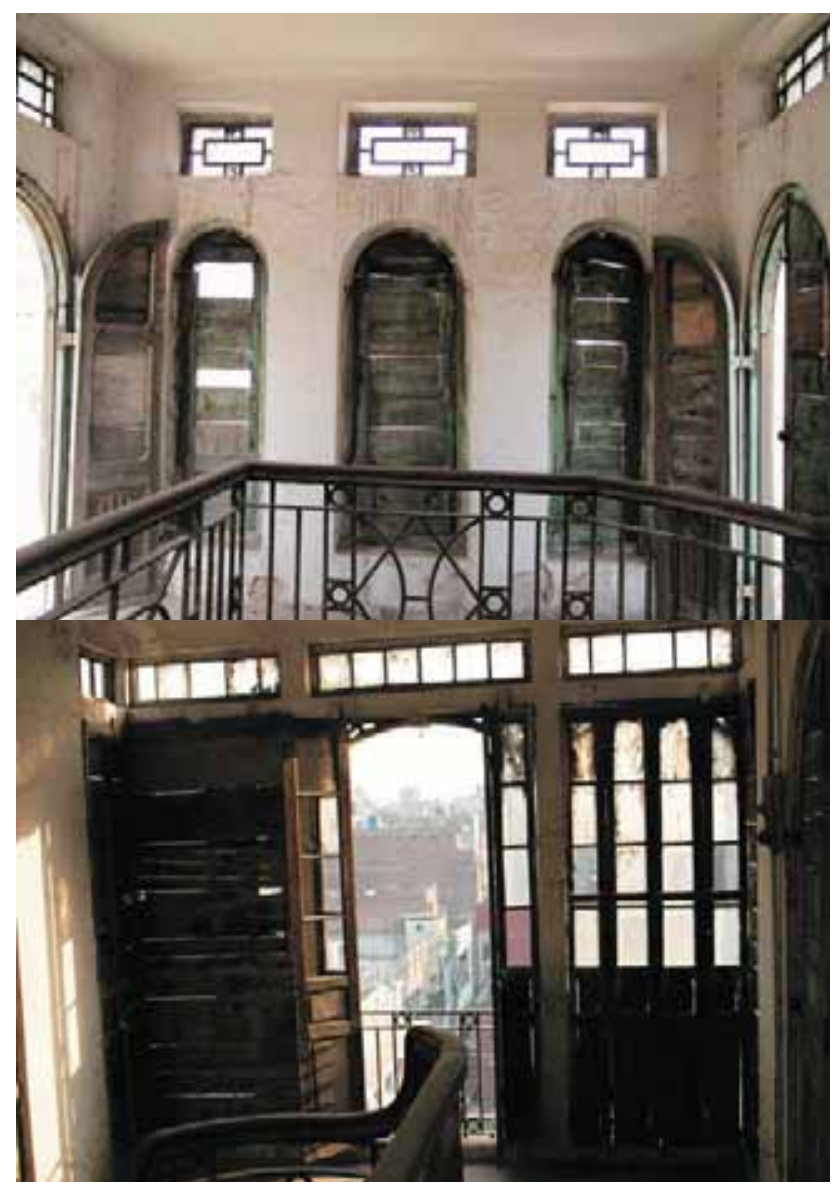

Figure-21: Wooden windows in the interior of the haveli.

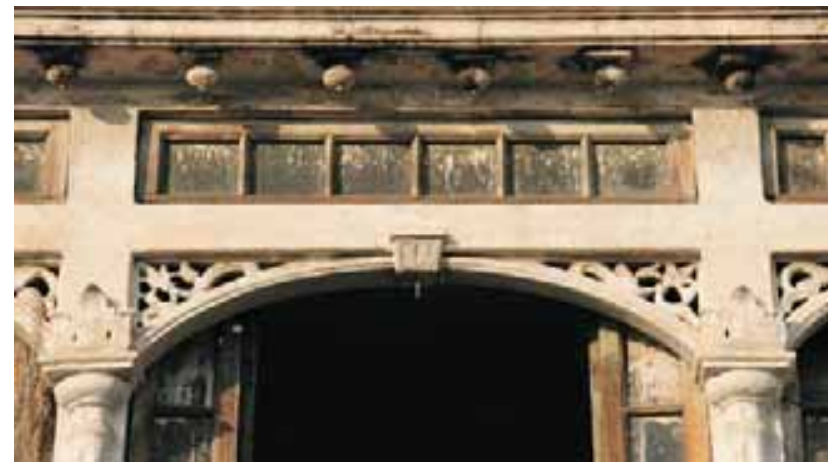

Figure-23: Rajput arch framing the doorway.

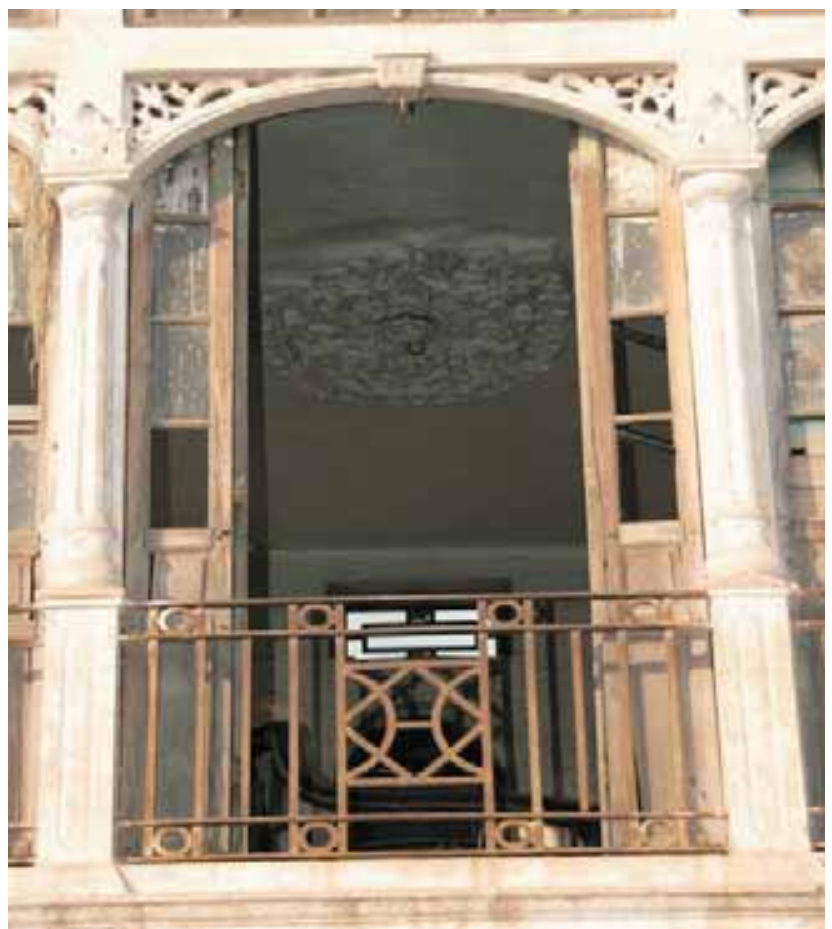

Figure-22: Rajput arch framing the doorway.

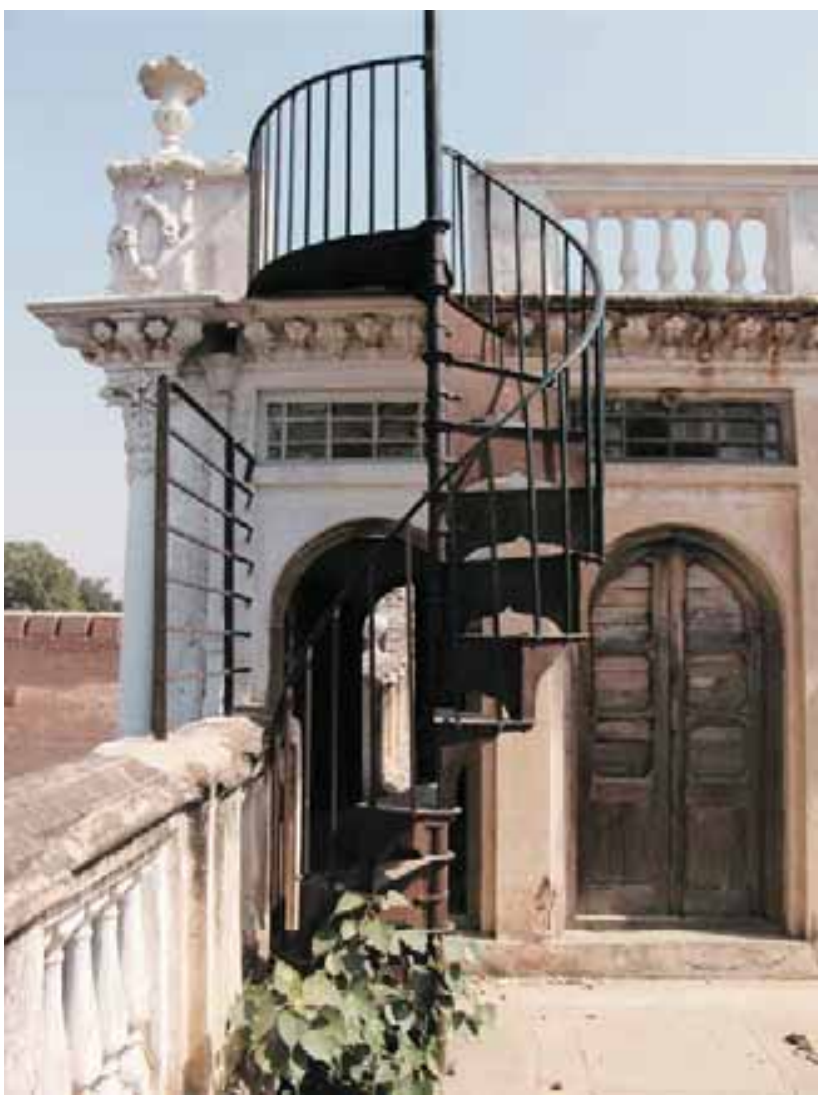

Figure-24: Terrace on right, showing the staircase leading to the rooftop 
double height with each wall having, atleast four to six windows, making the rooms well lit and having proper ventilation. Some wooden doors and windows used in its construction are still in their original condition. Each room has an open space in front of it, which become internal courtyards with openings, making the place comfortable. In winters these spaces are used to take sun bath by the family members of the haveli whereas in summers this courtyard helps ventilate the house. Thick walls (13 inches) also help to make the house cool in summers and warm in winters.

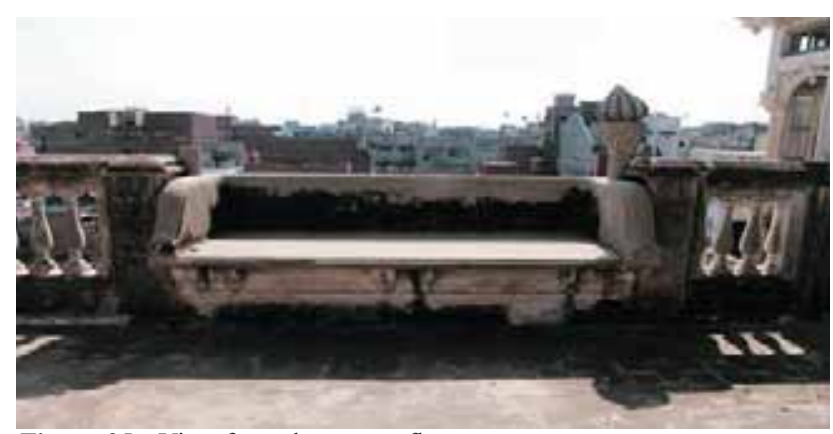

Figure-25: View from the mumty floor.

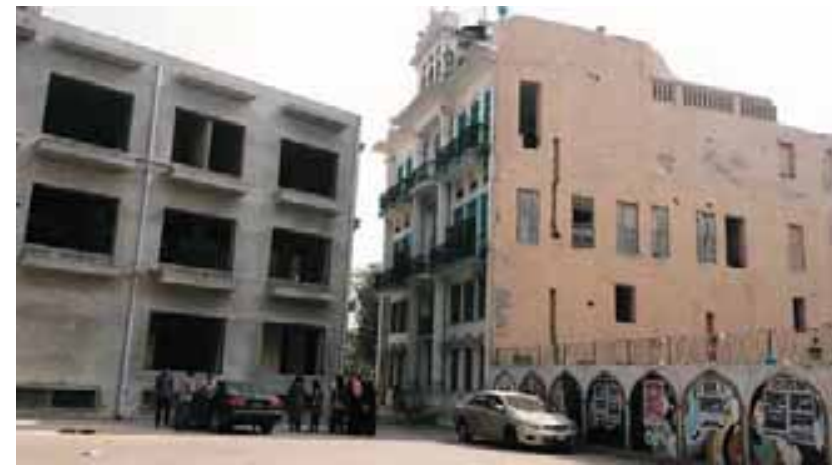

Figure-26: Rear side of the haveli.

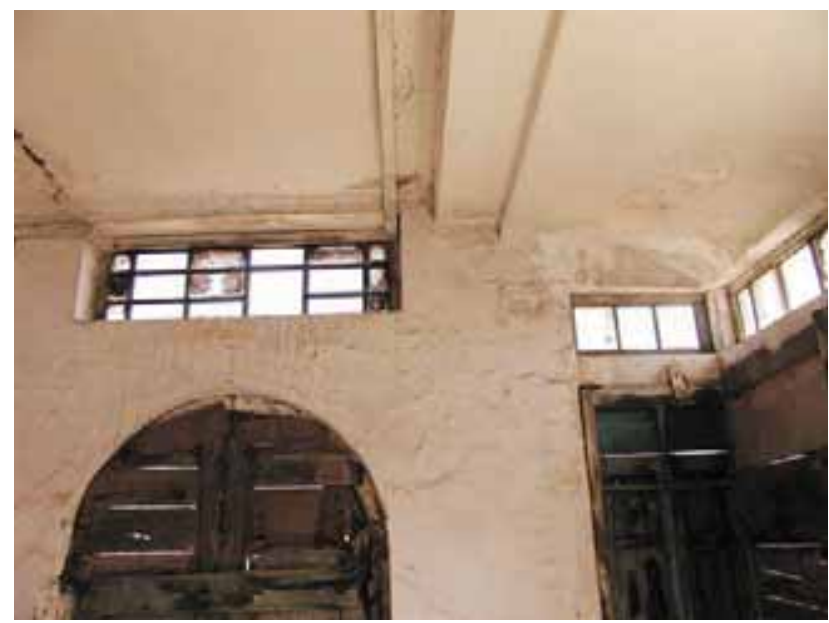

Figure-28: Dampness on walls seenin the interior.

\section{Conservation Significance}

It has been analyzed that in built heritage ageing has always been a vital factor of decay, but there are some other factors too which accelerate the deterioration of the monument. As per Sir Bernard "of the causes of decay in historic building, the most uniform and universal is gravity followed by the actions of man and then by diverse climatic and environmental effect" (Mughal, 1995). There is no single cause responsible for the deterioration and decay of Pirzada Mansion.

The neighbourhood of Pirzada Manison is now being used as a food street but previously it was not used as a public place but as a residential area. These havelis have now been converted into restaurants and cafes. Although this has been a successful social attempt to bring people, to the old parts of Lahore yet there are parking issues, issues of traffic flow and emission of carbon monoxide which damages the façade of the historical buildings. No proper garbage disposal system is in place and there is absenc of dustbins, street furniture, water dispensers and garbage collection systems. Some of

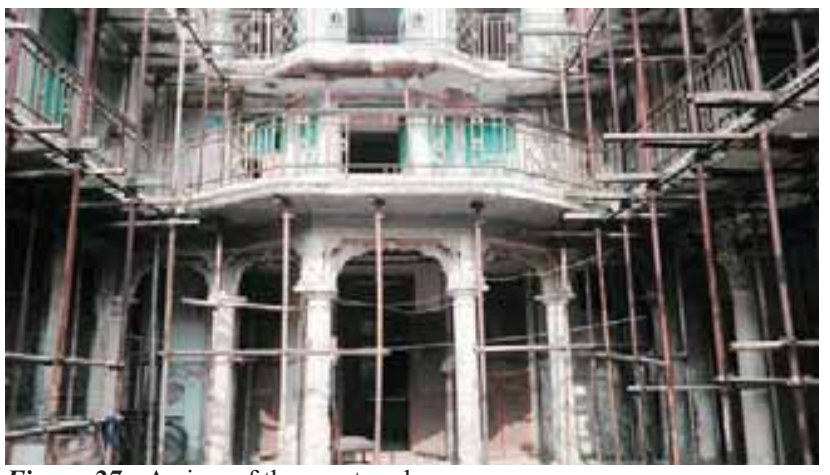

Figure-27: A view of the courtyard.

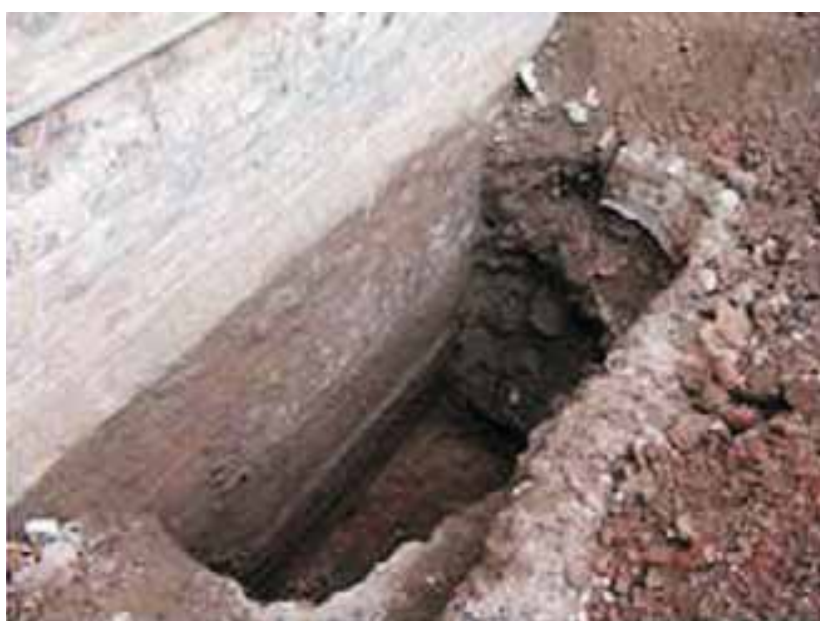

Figure-29: Unstable soil conditions in the contect. 
the other reasons behind the deterioration of the haveli are discussed in detail in the following section.

\section{Rain and Moisture}

In Lahore the average rainfall is twenty inches annually. Rain has damaged the masonry above the ground level and penetration of rainwater through capillary action has caused decay of structure internally. At some places in the haveli, this water penetration has also caused dampness (Figure 28).

\section{Topography and its Effects}

The nature of the ground and stability of soil, on which the building is erected are of an utmost importance. The site is located in an area with up to thirty feet of back fill, making it extremely unstable. Normally the back fill is upto $3 \mathrm{ft}$ (Figure 29).

\section{Man Made Causes}

The haveli has also been adversely affected by political instability in the region, general neglect and traffic and air pollution within the immediate context.

\section{CONCLUTIONS AND RECOMMENDATIONS}

A detailed study of the architectural significance of the building, that is located in one of the oldest parts of Lahore, concludes that the building has seen years of wear and tear under all kinds of weather conditions. Apart from the natural deterioration to the various parts of the building that has led to the structural cracks and depletion of the structure of the mansion, the whole structure is standing on scaffoldings which is a threat to the structure. The owners are no more interested in retaining the structure and they want it to be demolished and a new building to be builtin its place. Wasif Ali Associates Design office, an architectural firm, was approached to propose on the location a five star hotel, but due to serious structural threats it was advised that instead of the original structure, a new structure for the new function should be built by demolishing either the whole structure of Pirzada Mansion or parts of it. This proposal was not approved by the Walled City Authority and they have taken a stay against the demolition of the structure. The major objective behind this research was to recommend the idea that the haveli should be preserved for future generations. It not only adds to the cultural heritage, but is an example of a rich architectural edifice having interesting elements and features. In contrast to the adaptive re-use of the building, it should be restored or conserved on priority basis with immediate and long term plans. The objective of retaining its original usage is that, at times, the original identity of the building is lost while preparing it for adaptive re-use. And for this reason the proper conservation plan must be made first.

Sensible maintenance and repair can reduce the necessity for restoration work in historic buildings, as it is extremely important to maintain the originality of historic building, with minimum interventions. A detailed conservation plan is essential before carrying out any restoration work, as it helps to decide which part of the building needs replacement and which part can be preserved after minor repair. "Any intervention must be minimum, necessary and be allowed the maximum amount of existing material to be retained." (Fielden, 2003) As already mentioned, after the foundation survey, it was clear that the foundation of the building is highly unstable. In order to enhance the structural support and to resolve the problem, piling is the immediate solution. Furthermore, regular pointing and grouting is necessary. It is necessary to restore the surrounding environment of the building. Surroundings must be kept clean. It is also necessary to use the original material in case any conservation work is done to restore the building.

The conservation of a heritage building is generally perceived to be in the long term interest of the society as built heritage plays a very important role in developing the identity of a city. It helps people to stay connected to religion, traditions, culture and beliefs. This study directs towards the requirement for a proper conservation policy to be initiated by the government, that should take measures for the conservation of heritage buildings and respect the Antiquities Acts that was made for the sake of protection of old heritage buildings. Pirzada Mansion requires the attention of the Government of Pakistan. Heavy traffic flow should be discouraged near the haveli, as according to the Antiquity Act of 1975 no vehicular traffic or construction should be done within 2000 $\mathrm{ft}$ of a historic edifice. This and similar laws and policies should be enacted to help preserve this and other such buildings. 


\section{REFERENCES}

Arshi, P. S., 1985, Sikh Architecture, Delhi.

Browne, P., 1942, Indian Architecture: Buddhist and Hindu Period, Tobey Press, India

Fatima Q., 2013, "Haveli Bakhshi Ram-A Unique Potohar Architecture”, viewed- 02-05-2017., from https://quratulainfatima.wordpress.com/2013/02/10/haveli-bakhshi-ram-a-unique-potohar-architecture

Fielden, B. M., 2003, Conservation of Historic Building, Architectural Press, London.

M. R. Mughal, 1995, Legislation for the Protection and Management of Archeological Heritage of Pakistan: UNESCO: Educational Publishers, Karachi

Pakistan Environmental Planning and Architectural Consultants Ltd. (PEPAC), 1993, "Monograph of the Walled City of Lahore", Pack Art Press (Pvt) Ltd., Lahore. 